\title{
DIAPAUSE IN AQUATIC INVERTEBRATES:WHAT'S KNOWN AND WHAT'S NEXT IN RESEARCH AND MEDICAL APPLICATION?
}

\author{
Victor R. Alekseev \\ Professor, Zoological Institute of the Russian Academy of Sciences, St. Petersburg, Russia. \\ Jiang-Shiou Hwang \\ Professor, Institute of Marine Biology, National Taiwan Ocean University, Keelung, Taiwan. \\ Mei-Hui Tseng \\ Associate Professor, School of Occupational Therapy, Medical College, National Taiwan University, Taipei, Taiwan., \\ mhtseng@ntu.edu.tw
}

Follow this and additional works at: https://jmstt.ntou.edu.tw/journal

Part of the Aquaculture and Fisheries Commons

\footnotetext{
Recommended Citation

Alekseev, Victor R.; Hwang, Jiang-Shiou; and Tseng, Mei-Hui (2006) "DIAPAUSE IN AQUATIC INVERTEBRATES:WHAT'S KNOWN AND WHAT'S NEXT IN RESEARCH AND MEDICAL APPLICATION?," Journal of Marine Science and Technology. Vol. 14: Iss. 4, Article 9.

DOI: $10.51400 / 2709-6998.2088$

Available at: https://jmstt.ntou.edu.tw/journal/vol14/iss4/9

This Research Article is brought to you for free and open access by Journal of Marine Science and Technology. It has been accepted for inclusion in Journal of Marine Science and Technology by an authorized editor of Journal of Marine Science and Technology.
} 
DIAPAUSE IN AQUATIC INVERTEBRATES:WHAT'S KNOWN AND WHAT'S NEXT IN RESEARCH AND MEDICAL APPLICATION?

\section{Acknowledgements}

We acknowledge the financial support from Taiwan (NSC 94-2311-B-019-009), and Russian (05-0490588-HHC_a) bilateral collaboration. Furthermore, we are grateful for the partial support of the RussiaJapan grant (05-04-50914- $\Phi_{-}$a) for our study in space, and partial support from Center for Marine Bioscience and Biotechnology, National Taiwan Ocean University to JS Hwang. 


\title{
DIAPAUSE IN AQUATIC INVERTEBRATES: WHAT'S KNOWN AND WHAT'S NEXT IN RESEARCH AND MEDICAL APPLICATION?
}

\author{
Victor R. Alekseev*, Jiang-Shiou Hwang**, and Mei-Hui Tseng***
}

\section{ABSTRACT}

Dormancy is a profound and ancient adaptation found in a wide spectrum of plants and animals of all habitats. In diapause the switch between active and dormant states is driven by hormonal mechanism that usually includes a photoperiodic pace-maker. Temperature, food limitation and some other stress factors as well are shown as driven by diapause induction in aquatic invertebrates. In the last decade, diapause studies from a wide variety of topics have demonstrated that diapause switch mechanisms may be developed to create novel applications in biotechnology. Resting eggs accumulated in the surface lake sediments represent a "bank" of zooplankton species that assures their persistence in a community, in spite of periodic harsh conditions.

Studies on the vertical distribution of resting eggs in sediment cores yield useful information to opening important perspectives for paleolimnological climate reconstruction and paleoecology. Cultivation of live food, like rotifers, Daphnia, Artemia or marine copepods is an expanding application of practical use of diapause in modern aquaculture. Biotechnologies can now be imagined for maintaining ecosystems outside the Earth's biosphere. Resting stages provide at least two properties highly suitable for such ecosystems. They can be easily transported in space for a long time without special care as compared with an active ecosystem. Also, a storage of seeds and diapausing animals will provide a reserve in case of an unpredictable destruction of the active part of an ecosystem caused, for example, by a meteorite strike.

The term alien species takes on a new meaning when one considers another aspect of space biology. By enlarging the distribution area of the species, colonization of new environments could be a safeguard against its extinction. Thus it would also be important to develop technologies to guard against invasions of other species via ship ballast waters and similar means..

We also suggest that molecular genetic insights of diapause in invertebrates provide new ways of looking at carcinogenesis. Tumour cells may have parallels in post-diapause embryonic cells.

Paper Submitted 06/29/06, Accepted 10/17/06. Author for Correspondence: Mei-Hui Tseng. Email: mhtseng@ntu.edu.tw.

*Professor, Zoological Institute of the Russian Academy of Sciences, St. Petersburg, Russia.

**Professor, Institute of Marine Biology, National Taiwan Ocean University, Keelung, Taiwan.

***Associate Professor, School of Occupational Therapy, Medical College, National Taiwan University, Taipei, Taiwan.
The first diapause studies became possible only in the early $20^{\text {th }}$ century, when new quantitative approaches made it possible to estimate seasonal rhythms. This interest in seasonal alternation of active and resting life cycle periods triggered a proliferation of sub-fields in botany, entomology, ornithology and mammology. Noticeable progress in theory, and then practice, was achieved in these fields [43]. Only after mid-century, however, did data on the formation, progression, and significance of diapause in the life cycle of aquatic invertebrates begin to be understood, along with understandings of research on a narrow range of systematic groups $[54,109,110,132]$. In addition, only in recent years have the results in this field of study been generalized in a preliminary fashion for crustaceans $[6,16$, 44]. This paper reviews diapause in aquatic invertebrates and presents its recent scientific and practical applications.

\section{Definition and peculiarities of diapause in aquatic organisms}

In both continental and oceanic waters, aquatic organisms exhibit conditions that are characterized by wide ranges of heterogeneity. This heterogeneity is mainly determined by the annual cycle of solar radiation and is also influenced by wind and water current activity and directions [90]. The two main strategies organisms use to adapt to environmental heterogeneity are resistant and tolerant strategies. The first is based on responses to stress either at an individual or group level, actively overcoming environmental stress. Migration is an example of resistant strategies [67]. Tolerant strategies are characterized by minimizing vital functions or/and forming resistant (dormant) stages.

At high and mid-altitudes, and at different times in the tropics, invertebrates adapt to seasonal conditions by adjusting their life cycles to these periodic fluctuations in external factors. Periods of reproduction and 
population growth may either shift to certain periods of the year, or be delayed during unfavorable periods. As a result, life cycles can be seen as having alternating periods of active reproduction and population growth with periods where these processes are delayed, or stopped. The latter has been called dormancy. The best-defined types of dormancy according to the cause of the arrest in development are diapause and quiescence. Quiescence is driven directly by the dynamics of environmental factors, whereas diapause is determined by a predictive mechanism combining environmental signals and an internal hormonal mechanism [43]. The regulatory hormonal system acts at the organism and the single cell level. It always includes both inhibition and stimulation of vital processes [28].

A wide range of aquatic organisms exhibit diapause, or similar dormancy states (Table 1). It is interesting that, practically in all plant and animal phyla studied, photoperiod plays a leading role in the seasonal biological clock of organisms. Professor Alexander Danilevsky, the founder of a school of photoperiodism in invertebrates, argues that the mechanism of photoperiodic response is based on a common principle in all organisms. His ideas are supported by a comparison of photoperiodic responses (PPR) in the induction of insect, crustacean, rotifer and even plant diapause [6, 96, 121].

These aquatic organisms share many similarities, not only in common principles but also in details of diapause induction, termination and life cycle organization [6]. This suggests a monophyletic origin of this ancient adaptation and a similarity in the molecular basis and genetics of diapause mechanisms among these organisms.

The adaptive function of diapause applies both to biorhythms and defensive responses [43]. Biorhythms determine synchronization of the life cycle with environmental seasonal rhythms. Defensive traits allow an organism to endure the actions of the complex set of suppressive or even lethal factors occurring during an unfavorable period.

The defensive function of diapause provides an organism unspecific resistance to a wide complex of unfavorable actions. It is based on reducing the metabolic rate. In the case of anabiosis, the metabolic rate approaches zero [126]. Secondly, a variety of protective structures can be formed. Typically their size and characteristics, both morphological and physiological, help maintain a good viability level until the end of the harsh environment [50]. Examples are gemmules, shelves of resistant eggs, cysts, cocoons, statoblasts and ephippia [75]. Diapausing eggs may even maintain viability after passing through the digestive system of a predator, while normal eggs of the same species are digested [60].

Diapausing eggs contain nutritive storage substances. Given the depressed metabolism, the quantity of storage substances can suggest the duration of diapause [137].

Consequently, the post-diapause (exephippial) generation may grow faster, mature earlier and have greater fecundity than the individuals from parthenogenetic females [20, 21]. In addition, the exephippial individuals also have significantly higher levels of metabolites than individuals from parthenogenetic eggs [23]. As a result, the daphnids hatching from diapausing eggs are better adapted to optimal environmental conditions, while those from parthenogenetic eggs are better adapted to an unpredictable environment [22].

Table 1. Diapause in aquatic organisms [6]

\begin{tabular}{llll}
\hline Types, classes & \multicolumn{1}{c}{ Species } & Diapausing stages & Suppressed function \\
\hline Diatomea & Coicinodiscus coicunus & Aukospora & Development \\
Spongia & Halichondria panices & Gemmules & Development \\
Coelenterata & Aurelia aurita & Plannules & Embryogenesis \\
Turbellaria & Hemaniella retunuova & Eggs & Embryogenesis \\
Nemertini & Prostoma graescense & Cysts & Growth \\
Rotatoria & Notommata copeus & Eggs & Embryogenesis \\
Polychaeta & Dinophilus teaniatus & Cysts & Growth \\
Oligochaeta & Aelosoma hemprichii & Cysts & Growth \\
Crustacea & Daphnia pulex & Eggs & Embryogenesis \\
Insecta & Culex pipiens & Eggs & Embryogenesis \\
Mollusca & Sepia officinalis & Larvae & Maturation \\
Bryozoa & Lophopodella carteri & Statoblasts & Development \\
Echinodermata & Stichopus japonicus & Adults & Growth and breeding \\
Pisces & Nothobranchius gardneri & Eggs & Hatching \\
\hline
\end{tabular}


Physiological functions are suppressed in diapause. In larval and adult diapauses, there is a reduced rate of oxygen consumption (Figure 1). In addition, other functions (nutrition, mobility, reproductive activity) are also suppressed [7,62]. Defensive functions may be met from a combination of physiological and behavioral responses, including such things as vertical and horizontal migrations and searching for shelters [8]. Even though the combination of behavioral, constitutional and metabolic elements is usually species- or even population-specific, there are many common features in the range of each type of diapause.

The duration of diapause is determined by the combined effect of four general groups of factors. These are genetic characteristics, the result of selective mechanisms, environmental constraints, and the organism's physiology [58]. However, typically the decrease of oxygen consumption is most important in determining diapause duration (Figure 1). The relative importance of other factors varies according to the situation.

During the period of adverse environmental conditions, diapause preserves an adequate number of viable individuals from a species-population to assure its permanence in the community [43]. And yet, to achieve this aim the duration of the diapause can neither be too short nor too long. It cannot be shorter than the period of unfavourable conditions; neither can it be so long that the mortality in the passive individual increases greatly from such things as predation and bacterial and fungal infections $[6,46,82]$.

\section{Ecological stimulants of diapause in aquatic organisms}

What conditions argue evolutionarily for diapause? What are the factors which suggest diapause is necessary in an organism's life cycle? There are at least two demands, that diapause be both important for life and

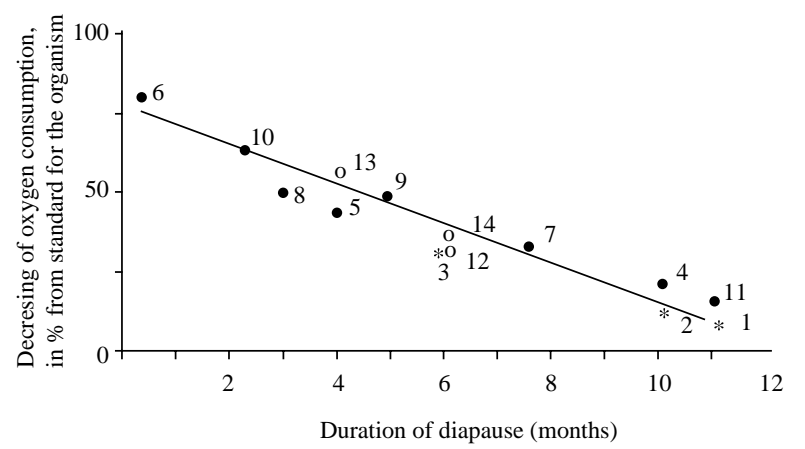

Fig. 1. The correlation between duration of diapause and decrease of oxygen consumption for crustaceans. 1-3, species with embryonic diapause; 4-11, species with larval diapause; 12-14, species with abult diapause [11]. occur in a periodic fashion. Such factors would guarantee the appearance of diapause and likely lead to its natural selection in populations [120].

Seasonality occurs from the subtropics to the arctic. These meteorological rhythms lead to cyclical pulses of the main factors important for life. This is equally true in the atmosphere, on land and in both continental and oceanic waters. For the overwhelming majority of aquatic organisms the warm season of the year is the most favorable. In high latitudes it is often the only period in which life functions can thrive. The appearance of favorable temperatures is determined by one of the most stable processes, the revolving of the Earth. Therefore, seasonal fluctuations of temperature should be regarded as one of the most important factors triggering development of diapause among aquatic invertebrates.

Periodic trophic conditions are also essential regulators for aquatic animals. The significance of trophic factors in the induction of diapause has been experimentally supported many times [71, 112, 117, 135]. For many crustaceans, especially those who live near the bottom of the deepest part of highly trophic basins, the winter and summer decline of oxygen concentration likely triggers diapause, and leads to the interruption of active development [14, 81].

Another periodic factor is predation. Outside of tropical waters, the pressure of predators, especially juvenile fish, is a likely trigger. Some authors consider it to be the main cause of the appearance of diapause in these habitats [55, 87].

Two main strategies appear to have evolved to help aquatic invertebrates avoid fish predation. One is migration into oxygen depleted zones to find a refuge. This has been shown for cyclopoid copepods [51, 98, 122]. Diapause in cyclopoid copepods reduces basic metabolism so they are able to remain in refuge for months until juvenile fish leave the plankton for near shore areas [13, 14].

Another strategy to avoid fish predation is to form resting eggs that are stable enough to survive passage through fish digestive systems [60]. If these eggs can still reactivate later, at least part of the population will survive until the beginning of the next season. This adaptation has been found in some clones of large sized Daphnia magna living in shallow ponds [95, 103].

In some water basins diapause may also lead to a decrease of the crustaceans' survival or even lead to their extinction from certain ecosystems [6]. In the diapause state, along with reduced metabolism, their behavioral reactions and speed are also reduced.

A special factor that selects organisms for their ability to form diapausing stages is the drying of temporary basins. Field data and experimental analyses show that dormancy is present in different orders of crusta- 
ceans inhabiting temporary basins $[3,35,84]$.

In temperate and polar areas dormancy seems to be a common strategy for surviving low temperatures. Earlier authors have argued that this proves dormancy originated in these regions. It is clear, however, that other forms of seasonality in tropical regions are equally unique. One periodic influence is monsoon rainfall [131], supported by studies of oceanic calanoid copepods from tropical upwelling environments $[61,92,119]$. The periodic lack of biogenic income from the deeper layers is similar to the situation in basins that dry seasonally. Because the gradient of trophic conditions is huge near algal blooms and regions outside of the upwelling zone, the crustaceans, which occur outside of the bloom or that experience the end of a bloom, feel the same as if their environment has "disappeared." In such situations some calanoid copepods, for example Calanus hyperboreus, demonstrate the ability to form diapausing stages. These stages sink to a depth of $400 \mathrm{~m}$ where low oxygen concentrations occur. Here they stay until new local upwelling lifts them up to the surface. When this happens they again start new generations that will find themselves in a temporary flowering "oasis" of food.

In the middle of the last century it was postulated that the ability of invertebrates to form diapausing stages decreased from high latitudes to the equator. It was speculated that this would occur because of the reduction of hydro-meteorological seasonality [43]. More recently, investigations indicate that this idea should be revised. It is now evident that diapause appears wherever annual or seasonal rhythmic fluctuations of important life factors take place [6, 8].

\section{Resistance to toxins in resting stages}

Resting eggs of many species of aquatic invertebrates and plants as well as spores of fungi and bacteria express a very high stability in the presence of toxic agents of different origin. Some are chlorine and insecticides [4], heavy metals including mercury [74], formalin and other organic poisons [138]. This non-specific resistance is based both on suppressed metabolism in these stages and special selectivity in the propagule membrane [57]. Resistance to toxic agents in some species can persevere. In nematodes resistance was tracked for 10 years [138].

An overview of data on resistance to toxic matter found in diapausing stages of aquatic organisms is given (Table 2). Such data suggest even wider possibilities for resting stages to overcome extremely harsh conditions in the environment and during transportation (e.g., in ship ballast water).

A sense of the protective functions of membranes can be found in the fire shrimp A. salina. Resting stages of this species could survive in a mercury solution 10 million times the concentration toxic to normal stages (Table 2). These embryos survived inside the protective membrane and immediately died after release from the membrane. Imitating the situation with ballast water, clear water was used after a 3-day treatment in toxic water. In these studies the embryo survived and successfully grew (Alekseev's personal observation, unpublished). The membrane therefore is impermeable to poisons but permeable to water and oxygen [74].

\section{INDUCTION OF DIAPAUSE}

For well over a century it has been clear that sexual reproduction and the appearance of diapause eggs (ephippia) can be triggered by changes in ecological factors such as temperature, food source and population density [128].

Banta and Brown [25] showed that female parthenogenesis could account for up to 800 generations of Daphnia pulex. However, by manipulating temperature, quantity of food and population density, males could be easily induced. Berg [27] suggested that the appearance of males was a function of the physiological state of females (stress theory). This state could be achieved once a background state of unfavorable factors was present. This occurred with a range of many factors, and thus was not specific [85]. Diapause induction occurred under the influence of isolated factors such as starvation [117], low temperature [56], food quality [99], diseases of females [135], pH [86], predator's smell [103], alarm signals [95] or the presence of some insecticidal hormones [91].

The first experiment conducted by Fries [49] on $D$. magna showed that photoperiod, together with temperature, triggered gamogenesis. Then Stross [110, 112] determined that photoperiod is an essential factor for daphniid life cycles to synchronize with seasonal rhythms of the environment. Other investigations also showed that this factor is very significant in the transition of Cladocera to sexual reproduction and induction of their embryonic diapause [32, 66, 100, 101].

Photoperiod also plays a leading role in the induction of embryonic diapause in Calanoid copepods. In the marine environment Marcus' $[77,80]$ works proved that the ratio of day to night determines the percentage of diapause eggs in sacs of the copepod Labidocera aestiva. These calanoids at times completely stop laying subitaneous eggs under the influence of this factor.

Hairston and Olds [60] showed the role of photoperiodism in causing the freshwater copepod Diaptomus sanguineus to switch from laying subitaneous eggs to producing diapause eggs. These authors also showed 
that photoperiodic responses of populations from neighboring basins were different. This difference might be caused by differences in trophic conditions and population densities, which, together with photoperiod, participate in diapause induction. Also, maternal effects might influence the diapause signal in these populations, as they do for some cladocerans $[9,10]$.

In general, it should be assumed that embryonic diapause induction depends essentially on seasonal fluctuations of night and day lengths. Other factors may also operate to induce this type of diapause but very often they work along with photoperiod.

Investigations of larval diapause in cyclopoid copepods show that similar factors trigger diapause. Some causal factors triggering a change from active development to dormancy are lower water temperatures [88, 122], food depletion [87], oxygen depletion in the hypolimnion [47], $\mathrm{H}_{2} \mathrm{~S}$ contamination and foraging by fishes $[55,87]$. Further experiments proved the essential role of seasonal fluctuations of day and night lengths in induction of larval diapause for freshwater cyclopoids
$[3,37,111]$.

Experimental research on some decapod crustaceans also proved the essential role of photoperiod in the induction of adult diapause $[1,2]$.

All of the above examples are facultative types of diapause. Obligatory diapause is genetically fixed, and does not require an inductive mechanism. In these cases, reactivation conditions become the most important consideration [43]. Monocyclic development of many species may be overcome by environmental factors. A good example of this is the experimental manipulation causing a doubling of the number of molts and missing of diapause in the crayfish Astacus astacus from Sweden [129].

In summary, the following are the main inductive factors for invertebrate diapause: photoperiod, trophic conditions, temperature, and population density. All may usually act in combination but sometimes independently. Effect of density may be manifested either through food supply or by signal action of chemical and/or behavioral agents.

Table 2. Maximal concentrations of toxic agents in which embryonic development of aquatic invertebrates takes place in experimental and field conditions $[4,74,75]$

\begin{tabular}{|c|c|c|c|c|c|c|}
\hline Classes, orders & Species & Resting stages & Toxic agents & $\begin{array}{l}\text { Toxic/ notoxic } \\
\text { solution, times }\end{array}$ & $\begin{array}{l}\text { Duration, } \\
\text { days }\end{array}$ & Reference \\
\hline \multirow{2}{*}{$\begin{array}{l}\text { Porifera, } \\
\text { Demospongia }\end{array}$} & \multirow[t]{2}{*}{ Ephidaria sp } & \multirow[t]{2}{*}{ Gemmuls } & $\mathrm{K}_{2} \mathrm{Cr}_{2} \mathrm{O}_{7}$ & 6250 & 5 & 2 \\
\hline & & & Formalin & 200 & 5 & 3 \\
\hline \multirow{3}{*}{$\begin{array}{l}\text { Bryozoa } \\
\text { Phylactolaemata }\end{array}$} & \multirow{3}{*}{$\begin{array}{l}\text { Plumatella } \\
\text { fungosa }\end{array}$} & \multirow[t]{3}{*}{ Statoblasts } & $\mathrm{K}_{2} \mathrm{Cr}_{2} \mathrm{O}_{7}$ & 4650 & 5 & 2 \\
\hline & & & Phenol & 6200 & 5 & 3 \\
\hline & & & Formalin & 100 & 5 & 3 \\
\hline \multirow{2}{*}{$\begin{array}{l}\text { Crustacea } \\
\text { Notostraca }\end{array}$} & \multirow{2}{*}{$\begin{array}{l}\text { Triops } \\
\text { cancriformes }\end{array}$} & \multirow{2}{*}{$\begin{array}{l}\text { Resting } \\
\text { eggs }\end{array}$} & \multirow[t]{2}{*}{$\mathrm{Cl}-1$} & \multirow[t]{2}{*}{10000} & \multirow[t]{2}{*}{$5-10$} & \multirow[t]{2}{*}{1} \\
\hline & & & & & & \\
\hline \multirow[t]{4}{*}{ Anostraca } & \multirow{4}{*}{\multicolumn{2}{|c|}{ Artemia salina }} & $\mathrm{K}_{2} \mathrm{Cr}_{2} \mathrm{O}_{7}$ & 100000 & $3-5$ & 2 \\
\hline & & & Phenol & 156000 & & 3 \\
\hline & & & Formalin & 8000 & & 3 \\
\hline & & & $\mathrm{HgCl}_{2}$ & 10000000 & & \\
\hline \multirow[t]{4}{*}{ Conhostraca } & \multirow{4}{*}{\multicolumn{2}{|c|}{ Lymnadia sp. }} & $\mathrm{Cl}-1$ & 10000 & $5-10$ & 1 \\
\hline & & & $\mathrm{K}_{2} \mathrm{Cr}_{2} \mathrm{O}_{7}$ & 100000 & $3-5$ & 2 \\
\hline & & & $\mathrm{CuSO}_{4}$ & 2000000 & $3-5$ & 3 \\
\hline & & & Cl-1 & 10000 & $5-10$ & 1 \\
\hline \multirow[t]{4}{*}{ Cladocera } & \multirow[t]{3}{*}{ Daphnia cucullata } & \multirow{3}{*}{$\begin{array}{l}\text { Ephippii } \\
\text { (resting eggs) }\end{array}$} & $\mathrm{K}_{2} \mathrm{Cr}_{2} \mathrm{O}_{7}$ & 62500 & $3-5$ & 2 \\
\hline & & & Phenol & 31000 & $3-5$ & 3 \\
\hline & & & Formalin & 800 & $3-5$ & 3 \\
\hline & \multicolumn{2}{|l|}{ Daphnia magna } & Cl-1 & 10000 & $5-10$ & 1 \\
\hline \multirow[t]{3}{*}{ Ostracoda } & \multirow{3}{*}{\multicolumn{2}{|c|}{$\begin{array}{l}\text { Heterocypris } \\
\text { incongruens }\end{array}$}} & $\mathrm{K}_{2} \mathrm{Cr}_{2} \mathrm{O}_{7}$ & 4650 & $3-5$ & 2 \\
\hline & & & Phenol & 125000 & $3-5$ & 3 \\
\hline & & & Formalin & 320 & $3-5$ & 3 \\
\hline Cyclopoida & Cyclops strenuus & Copepodit & $\mathrm{Cl}-1$ & 10000 & $5-10$ & 1 \\
\hline
\end{tabular}


A further distinction can be made in all these inductive factors, between signals (among which photoperiod is the most important) and ecologically important conditions (e.g. trophic conditions). An important intermediate factor is temperature. In a certain range of conditions it acts as a signal; then, when its values exceed tolerance levels, as an ecological condition. The effect of density is analogous. The only difference is that the action of signal agents (metabolites accumulation, hormone secretion and/or tactil contacts between specimens) operates within tolerance limits (compared with temperature), and frequently acts in conjunction with trophic conditions. Among all these factors, photoperiod is the most stable and is closely correlated with the seasonal transformation in amount of solar energy.

\section{Diapause as a photoperiodic response}

There are two main groups of photoperiodic responses (PPR) in Crustacea: qualitative and quantitative PPR. Quantitative responses are changes of some measurable characteristic (e.g. body length, fecundity), which occur under the influence of an increase or decrease in day length. During qualitative PPR, organisms change between alternative states. These might include development with or without diapause, parthenogenetic reproduction or gamogenesis (Figure 2b, c).

Quantitative PPRs are more known among crustaceans with adult diapause. One such example - decrease of time intervals between moults - was found for the isopod Armadillidum vulgare [64].

As another example, Daphnia pulicaria, the first results obtained on the life cycle parameters affected by quantitative PPR were quite impressive [10]. In this species, photoperiod influenced the maturation time, the first clutch size, and even the survival of the parthenogenetic offspring.

Reserve materials, stored by diapausing organisms at the end of their previous season, are available and used at the beginning of the next season. Thus, even when food is limited, they serve as the basis for successful reproduction of cladocerans [115]. This conveniently reduces the divergence between the time of reactivation and that of the mass development of food organisms (especially phytoplankton microalgae).

PPRs may be divided into long-day and short-day ones according to the length of the photoperiod inducing diapause (Figure 2). These types are evidently alternative. With one species, a long day serves as a signal for transition to active development, whereas for another, it may be a signal to enter diapause. Most crustaceans develop throughout the warm period of the year and thus short-day PPRs are the most widespread.

PPRs may be presented as graphs, where day length (hours) is plotted along the $\mathrm{X}$-axis and the number of diapausing specimens (\%) or some other quantity is plotted along the $\mathrm{Y}$-axis (Figure 2). PPR-threshold (50\% response) is a very important statistic of the PPR. The range of the zone of reaction, which to some degree is due to population or clone polymorphism, is ecologically significant. Species with a narrower zone of reaction have less variation in their response to day length.

The PPR-threshold and the width of the zone of reaction regularly change under the influence of other factors (e.g. temperature), which participate together with day length in the realization of photoperiodic responses. All of this information permits phenological predictions [6].

When different species are compared, it may be necessary to identify species with the greatest plasticity
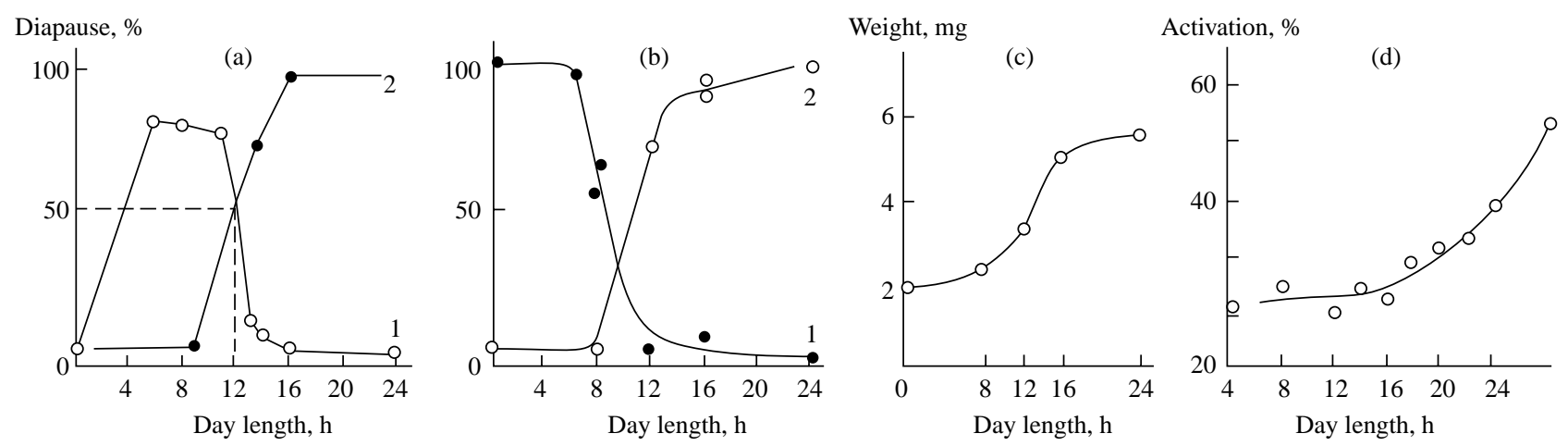

Fig. 2. Quantitative (a, b) and qualitative (c, d) photoperiodic responses (PPR) in Crustacea. a. Long-day and short-day diapause induction in Diacyclops navus and D. sp. (modified from Watson and Smallman [125]); b. Diapause induction in two alternative lines of Macrocyclops albidus (after Alekseev [3]); c. Growth of body mass in a phyllopod Streptocephalus torvicornis (modified from Roshina 1985); d. Activation of females in crevete Palaemones varians after winter diapause (after Bouchon et al. [30], with modification. 
in their response to photoperiod. This information may be useful for understanding the acclimatization and range expansion of introduced (alien) species [5, 94].

Appearance patterns of PPRs in aquatic organisms can be subdivided into gradual and threshold responses [6]. The latter appear in a narrow photoperiodic range, while the former occur throughout the whole range of photoperiods. Generally, threshold responses are characteristic for diapause, but they also involve other phenomena such as crustacean vertical migrations or mortality in different seasons [8]. Besides absolute (scalar) values of day and night lengths, the direction of the vector of photoperiod change (increase or decrease of day length) may also be essential for realization of PPRs by crustaceans [65].

Danilevsky [43] considered PPR-types to be a very fundamental adaptation because it determines the whole complex of environmental conditions for the species, such as temperature, food presence and predation risk. Most surprising are cases where contrasting responses to day length exist within one species, as noted for some insects [102] and the littoral cyclopoid Macrocyclops albidus [6]. Oddly, no reproductive isolation was found between the groups with long-day and short-day responses $[10,12,15,16]$.

\section{Effects of population density}

What are the possible signals for changes in population density? Some of these signals appear to be food cessation, worsening of food quality, increase in concentration of the signal (e.g. increase in metabolites, pheromones or hormones) or the number of tactile interactions. Ecological significance of these factors appears to vary widely.

The trophic conditions promoting transition to gamogenesis may reach significant levels rather easily even if population density of the consumer is relatively low [113]. This occurs through changes in structure or quality in food organism communities. On the contrary, necessary contents of metabolites or number of tactile interactions may be achieved only under high, particularly constant, concentrations of organisms. There is a suggestion that this limitation in high metabolite concentration may be removed when crustaceans become more sensitive to factors like metabolites and/or tactile interactions [103].

About a century earlier, the common belief was that the transition to gamogenesis was determined by worsening of trophic conditions. At that time some researchers suggested otherwise that, changes in the food quality was the most important [99]. Others considered that change in the type of reproduction was triggered by starvation [117]. Later, Von Denn consid- ered that food quality determined appearance and accumulation of fat in bodies of Moina macrocopa females and this, in turn, caused formation of males and ephippia.

These experiments, however, rarely took into account photoperiodic conditions, and this is believed to seriously compromise the results. The situation changed when gamogenesis induction studies carefully tracked photoperiod, density and temperature together [33, 34, $66,110,112]$.

The most detailed data on the combined effects of these factors on Cladocera gamogenesis induction was obtained by Stross [110, 112]. Using threshold densities, the effect of photoperiod (facultative, but rather essential from the ecological point of view) is expressed as the change necessary to trigger a change of reproductive mode.

In permanent basins, where populations are not large because crustaceans are eaten by predators (presumably fishes), dynamics of food conditions are likely the most important factor. However, in temporal basins where consumers do not limit the quantity of crustaceans, density becomes the most important factor. While moving from south to north, the signal effect of photoperiod noticeably increased. Starting at 20 hours of light, all females of Daphnia middendorffiana formed ephippia. This was independent of their density. However under day-and-night illumination the number of ephippial females was density dependent [116].

The combined effect of density and photoperiod on transition to larval diapause was registered in desert rain pools with the copepod Metacyclops minutus (Figure 3).

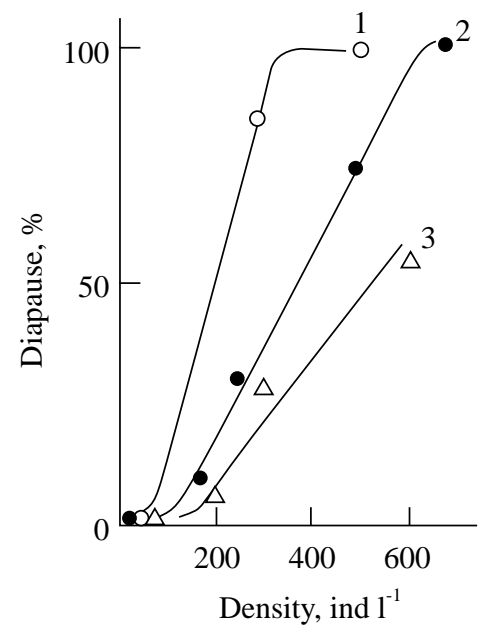

Fig. 3. Combined effect of population density and photoperiod on diapause induction in the cyclopid Metacyclops minutus. 1. day length 12 hours; 2. day length 16 hours; 3. day length 20 hours (after Alekseev [6]). 
Another population density phenomenon is the blockade of diapause induction for at least the first generation of cladoceran females hatching from ephippia. The theory of cladoceran immanent cyclic rhythms $[83,128]$ was based on this phenomenon. Blocking the system responsible for changes in the type of reproduction is probably connected with the reserve materials in diapause eggs. It may even be transferred from the female who left ephippium to her offspring [115]. The reproductive system of the founder is protected (at least temporarily) from the consequences of sudden food cessation. Therefore the real effect of trophic conditions is only felt later on. Such conservative reproductive strategies in crustaceans have definite adaptive significance and are directed to the fastest colonization of a basin at the very beginning of the vegetation period.

In nearly all cases where the combined effect of photoperiod and density on diapause induction has been studied, the density effect is limited by restriction of the optimal zone of PPR manifestation (see Stross [114] for review). Thus a species with a life strategy directed to rapid development in the presence of increasing food should also have a more rapid reaction to diapause induction. They must react to density changes faster than to photoperiod fluctuations. For example, Moina macrocopa actively develops under conditions of abundant organic matter. Its gamogenesis depends little on day length [71].

Low population density also frequently suppresses the regulatory function of photoperiod. In arid zones, low density in the inhabitants of temporal basins (Metacyclops minutus, for instance) is a signal about not expiring of food resources in environment.

Organisms with only a short active period in their life cycle, however, cannot allow themselves such a "luxury" like low population density [6]. For example, most Cladocera fertilization proceeds to diapause and therefore it is necessary that opposite sexes meet [104]. Efficiency of such meeting also depends on density.

\section{Temperature and diapause induction}

Temperature is assumed to have a double function in relation to developing organisms. First, within a tolerance interval, it directly affects growth and metabolic rates by increasing or decreasing the intensity of these processes. Second, it can either decrease or fully interrupt these processes when temperature moves outside the tolerance limits [63]. Temperature also participates in induction, development and termination of diapause [43].

Mechanisms by which temperature affects actively developing and diapausing organisms have been well studied, and many common features have been identified.

One example demonstrates the combined effect of both factors acting together and shows why they should not be considered separately. Photoperiod and temperature effects on gametogenesis were first studied in the cladoceran Daphnia magna [49]. Both the formation of ephippia by females and the appearance of males are regulated by different combinations of temperature and photoperiod. This happened in two combinations, either short days ( 4 hours of light) at $18^{\circ} \mathrm{C}$, or long days (20 hours of light) and $11^{\circ} \mathrm{C}$ (Figure 4). Photoperiod was influential on each response (appearance of males or ephippia) in a wide temperature range $\left(8-30^{\circ} \mathrm{C}\right)$ but gamogenesis in D. magna was most effective within a range of relatively low temperatures. Outside that range, light did not influence the process. Males did not appear at temperatures below $8^{\circ} \mathrm{C}$, while females could not lay ephippia at temperatures above $30^{\circ} \mathrm{C}$.

Temperature influences the formation of diapause eggs by the marine calanoid Labidocera aestiva [78]. When temperature was reduced, the PPR-threshold of this species within the range of tested temperatures shifted rather regularly to longer days. The gradient of this shift was about $2,5-3$ hours per every $5^{\circ} \mathrm{C}$.

Watson \& Smallman demonstrated a temperature
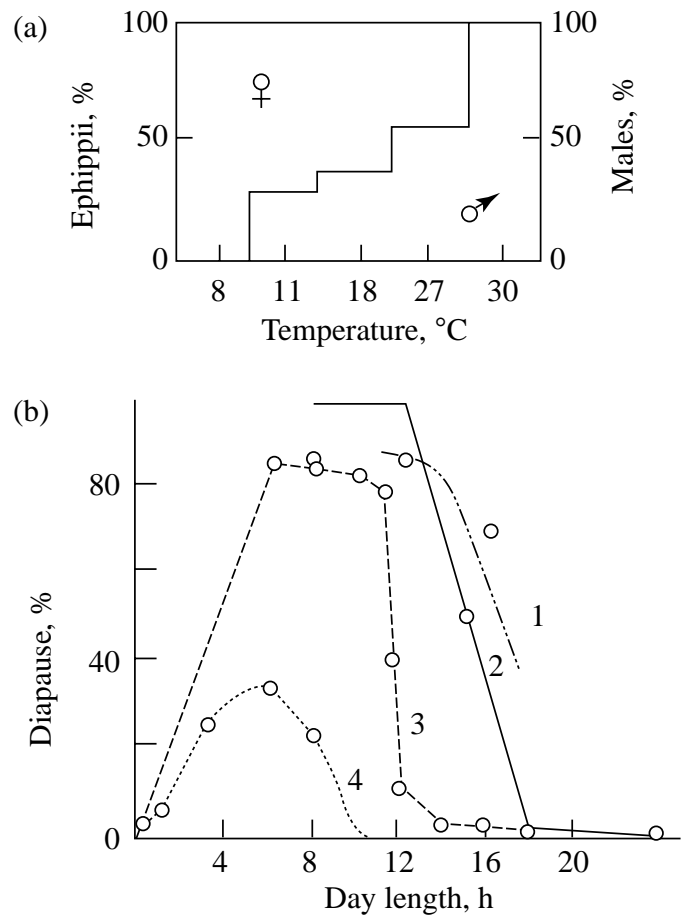

Fig. 4. Effect of temperature on male and ephippia production in Daphnia magna (a) and transformation of photoperiodic response in Diacyclops navus under temperatures as following: 1. $10^{\circ} \mathrm{C} ; 2.15^{\circ} \mathrm{C} ; 3.20^{\circ} \mathrm{C} ; 4.25^{\circ} \mathrm{C}$; (b) a. after Fries [49]; b. after Watson \& Smallman [126] 
effect on the propensity to form diapause stages by the freshwater cyclopid Diacyclops navus [126]. The temperature optimum for this response in Diacyclops navus was within the range of $10-25^{\circ} \mathrm{C}$ (Figure 4). Above this range, transition to diapause was inhibited regardless of photoperiod. Temperature below this range induced diapause independently of day length.

Most investigations evaluating combined effects (temperature and photoperiod) on reproductive cycles deal with the termination of adult diapause [30, 31, 77]. For example, the effect of photoperiod-temperature conditions on the annual cycle of the crayfish Astacus astacus was studied by Westin and Gydemo [129]. By modeling annual temperature rhythms, the authors found two periods of copulation and breeding (March-April and August-September) instead of the one which occurs in natural conditions.

Danilevsky asked what ecological value there was to PPR having a zone of optimal temperatures [43]. He found that the transition to diapause tends to be accompanied by accumulation of reserves and reconstruction of some metabolic pathways. Other changes may occur under favorable conditions. Photoperiod signals the approach of seasonal environmental changes. The effectiveness of this signal increases when cold (for shortday responses) or warm (for long-day responses) conditions approach. However, the signal function of photoperiod loses its adaptive value at temperatures outside the optimal range.

Temperature changes in water have a greater biological significance than those in air. Water has a greater specific heat than air and in any given day its temperatures fluctuate less. This may help explain the two-fold difference in gradient of PPR-threshold change in crustaceans ( 0.6 hour degree $\left.e^{-1}\right)$ as compared with insects $\left(0.28\right.$ hour degree $\left.{ }^{-1}\right)$ [6]. It seems possible that studies on the relationship of temperature and light on diapause induction of aquatic insects could help clarify the situation.

Although the temperature gradient of changes in PPR-threshold and the existence of temperature optima suggest a similarity of temperature effects on both actively developing and diapausing organisms, there is one essential difference. The change of direction of the temperature transformation (growing or decreasing) is opposite on short- or long-day diapause types.

Combined effects, in summary, happen when there is an interplay of primary signal (e.g. photoperiod) and physiologically important factors (e.g. temperature). Temperature, for example, may either strengthen or lessen the influence of photoperiod. When this occurs, it is necessary to understand both factors well, even in cases where only one of these factors seems to be essential.

\section{REACTIVATION PROCESS IN ORANISMS WITH DIFFERENT TYPES OF DIAPAUSE}

Diapausing crustaceans in the marine environment often stay on the bottom of deep sea basins where light is almost absent, and temperature conditions stable [123]. Diapausing stages of many freshwater crustaceans are primarily found in the deeper lightless parts of lakes, too [26, 51, 98]. What, then, triggers diapause reactivation? Literature reports are controversial. Meanwhile, photoperiod is a frequently mentioned candidate $[47,70,110]$. Consequently, research in which this factor was not considered or not controlled is now considered doubtful. Here we review diapause reactivation mechanism for each type of diapause separately.

\section{Embryonic diapause}

The first experimental reactivation of embryonic diapause with controlled photoperiod was done on Daphnia pulex ephippia [93]. Summer ephippia were put in darkness immediately after they were laid. At particular intervals, subgroups of these ephippia were exposed to a light regime approximating the light-spectrum of sunlight. Then the intensity of hatching was monitored. Time of hatching was found to depend on the previous period of darkness. When there had been $2-6$ weeks of darkness, maximum reactivation occurred within the first day. When the period of darkness was less than 2 weeks, reactivation - or diapause termination - radically lengthened to 6 weeks. Embryos that were maintained in constant darkness (control group) did not hatch. The author speculated that light was also an obligatory condition of summer diapause termination for $D$. pulex [93].

Winter diapause in the embryos of this species was interrupted by a long exposure (5.5 months) of ephippia at a low temperature $\left(3.5^{\circ} \mathrm{C}\right)$. The photoperiod effect was considered poor, meaning that light was not an obligatory condition for winter diapause termination. Stross' work [113], however, suggested that only one long-day light impulse (modeled by two short periods of illumination) might be enough to synchronize the end of embryonic winter diapause.

Uye et al. [123] used marine calanoids (6 species) collected from the shelf-bottom. The strongest triggers of reactivation were temperature and oxygen concentration. Light conditions had no influence.

Using Diaptomus oregonensis, Cooley [38] again found that temperature played a major role in triggering reactivation of diapausing eggs. Hatching rates corresponded to the amount of time embryos had spent under low temperatures. Maintenance of eggs under a constant high temperature prolonged the time before exit- 
ing from diapause, and reduced embryo survival. In both cases, however, embryos took 3 months to complete reactivation, even though in nature the eggs would be maintained at a low temperature until the end of reactivation. The minimal mortality under the lowtemperature regime suggests that this is the ecological norm of survival of diapausing embryos.

Nauplia of the brine shrimp Artemia salina (Phyllopoda) are economically important as a food in industrial fish breeding. Although Spectorova [106] studied diapause termination in this species, her methods and experiments were developed from a pragmatic interest in improving the technological aspects of culture. Such essential data as light and gas regimes are absent in these publications, nor are dates of sampling or egglaying typically mentioned. These omissions have led to some contradictions in the literature about A. salina diapause, and thus make additional experiments necessary. Despite the confusion, it is clear that oxygen is necessary for diapause termination in the embryos, and that light participates in synchronizing this process [29].

Early studies considered it necessary for eggs to be dried to accelerate reactivation of phyllopods. In 1964, however, Askerov and Sidorov reactivated eggs of Apus (Triops) cancriformis and Leptosteria sp. without drying the eggs [24]. Instead they used frequent water changes, which caused an increase in oxygen concentration.

Even though the factors that affect reactivation (temperature, photoperiod, oxygen concentration) are the same in winter and summer diapauses, their relative importance differs. For example, light is more important for summer diapause. Temperature sometimes strengthens, but sometimes weakens, the reactivation processes. The key factor in terminating winter embryo diapause is the duration of exposure to low temperatures. Light and oxygen then promote a more synchronized exit from diapause.

\section{Larval diapause}

Termination of larval diapause was originally considered to be linked only with the seasonal dynamics of temperature [97]. For example, Coker [36] found that when copepodites of Acanthocyclops vernalis maintained in their mud habitat under low temperatures were changed to a high temperature regime, diapause ended and the planktonic phase began [36].

More detailed data was obtained by Fryer and Smyly [51]. They collected diapausing cyclopoids (Mesocyclops leuckarti) in the pelagic zone in the normal winter diapause phase. However, regardless of whether they were kept under high or low temperatures, time of reactivation was the same. No record was kept of survival statistics.

Using the same species, Smyly [105] established that reactivation of individuals collected mid-winter could be triggered either by a rapid increase of temperature or by continuous maintenance at $4^{\circ} \mathrm{C}$.

Einsle's [47] studies on C. vicinus in Lake Constance showed that although oxygen depletion could delay reactivation, it could not interrupt it. Neither the presence of food nor light intensity had an effect on exit from diapause. Instead, day-length had the greatest effect on accelerated reactivation. The critical value was 15 hours of light.

Additional studies agreed that photoperiod was important in reactivation of the species [107]. A combination of day-and-night illumination with a temperature of $20^{\circ} \mathrm{C}$ was enough to cause Diacyclops navus to exit from larval diapause [125].

One area that has been poorly studied is the role of separate factors in the termination and reversibility of larval diapause. When studies were conducted to see how decreased temperatures interrupt early embryonic diapause, they did not control light conditions [37, 130]. As these experiments were performed in summer it is assumed that a long-day photoperiod facilitated this process.

Conclusions about larval diapause generally coincide with previous findings on embryonic diapause. The first stage of reactivation occurs under low temperatures. It is determined by the time of exposure to the temperatures. In the last stage, three factors may influence reactivation. Light (photoperiod), and/or a change of oxygen concentration, or temperature increase can accelerate reactivation.

\section{Adult diapause}

Transition of the shrimp Palaeomonetes pugio to diapause was reached by increasing the temperature from $10^{\circ} \mathrm{C}$ to $25^{\circ} \mathrm{C}$ [70]. The efficiency of this process depended on the day-length. Under a constant photoperiod $(10.5 \mathrm{~h})$ almost half $(43 \%)$ of the experimental animals reactivated. Longevity of reactivation was determined by the date of sampling [70]. Specimens collected mainly in November started to respond to photoperiod and temperature increased no earlier than two months after being transferred to laboratory conditions.

Crisp \& Putel [41] found that light could affect acceleration or delay of maturation in the cirripedian genus Balanus. It was found that in three different species (Balanus balanoides, B. balanus and B. crenatus) three different critical temperatures $\left(10-12^{\circ} \mathrm{C}, 10-14\right.$ ${ }^{\circ} \mathrm{C}$, and $17^{\circ} \mathrm{C}$, respectively) were necessary for 
reactivation.

Tsukerzis \& Shyashtokas [120] were able to induce early termination of diapause with the crayfish Astacus astacus. Females with eggs were collected at the end of December. Then they were kept at a constant temperature of $2-3^{\circ} \mathrm{C}$ for 15 days. Gradually the temperature was raised to $19-20^{\circ} \mathrm{C}$ and termination of diapause both in embryos and adults occurred in 45 days. That was almost 5 months earlier than observed in nature. Unfortunately, light conditions were not controlled or monitored in these experiments.

With the more southern species Astacus leptodactilus cubanicus the period of temperature reduction needed to reactivate individuals was half as long [118]. When this species had been transferred from nature to a temperature of $14-15^{\circ} \mathrm{C}$ its copulation began in January instead of April, as observed in nature. Again, the authors did not report on the photoperiodic conditions of this experiment.

Illumination and temperature were controlled in experiments by Westin \& Gydemo [129]. Manipulations of water temperature allowed for a doubling of the number of reproductive periods of the crayfish $A$. astacus. The authors concluded that light conditions affected neither induction nor termination of diapause. However, their conclusion was apparently premature. Even though by that time others had demonstrated the efficiency of directional change (increasing or decreasing) in photoperiod [65, 70, 108], Westin \& Gydemo did not consider directional change.

Such remarks may be applied also to reactivation of the shrimp Macrobrachium australense [68]. Symmetric values ( 0 and 36 hours of illumination) of photoperiod did not affect the initiation of copulation. Copulation started only after temperatures increased to 25 ${ }^{\circ} \mathrm{C}$. The time interval between first temperature increase and initiation of spawning depended on when the shrimp were collected. For those collected at the beginning of winter the interval was about 50 days. When they were collected at the end of winter, it was 30 days. And, in the middle of spring, it was about 10 days.

Diapause termination has been studied in isopod Acmadillidium vulgare. In different populations of this species Juchault et al. [66] were able to generalize the dependency relationship between reactivation time and latitude. Temperature had either a weak or nonexistent effect on reactivation time. Mocquard et al. [83] demonstrated the significance of photoperiodic conditions for synchronization of reactivation processes in this species.

In gammarid Gammarus lacustris, March [77] showed that during the last stage of diapause light conditions had a significant effect on terminating the diapause. Therefore, as a trigger, conditions of light eclipse those of temperature.

Many histological studies have looked at ovarian cycles of Decapoda [83, 87, 97]. They find that temperature and photoperiod are important for maturation of these crustaceans.

In summary, reactivation of adult diapause is similar to other types of diapause. In nature there is a rather long period under low temperatures. Transferring crustaceans to a high temperature during the refractory phase does not accelerate the process. Instead, it desynchronizes it and increases mortality [76]. Using this property of diapause, artificial termination of diapause can be induced in crustaceans. Reversal of diapause may also be achieved. Time of diapause termination may be prolonged.

This review shows that both induction and termination of diapause are caused by the action of a similar complex of external factors (e.g., photoperiod, temperature), but the relative significance, mechanisms, thresholds of sensitivity, and limits of action are different for induction and reactivation.

\section{RESEARCH APPLICATIONS IN SCIENCE AND TECHNOLOGY}

A wide range of research fields, including aquaculture, invasive species control and space programs would potentially benefit from a deeper understanding of diapause. The level of research, however, in this field at the moment is a tiny fraction of what it could be. We hope to stimulate such research by elaborating on some of the possible applications.

Although the influence of diapause at the population and community level is, of course, of great interest in ecology, few aquatic studies take diapause and its consequences into account because it is so difficult to quantify the order of magnitude of the individuals emerging from diapause $[6,45,59,79,133]$. This difficulty increases when individuals of the same species enter diapause, emerging at different times and producing overlapping cohorts.

Resting eggs (or other resting stages such as larvae, adult) accumulated in the surface lake sediments represent a "bank" of zooplankton species that assures their persistence in a community, in spite of periodic harsh conditions [34, 45, 62]. This strategy is of fundamental importance in aquatic studies on biodiversity and natural conservation [39].

Studies on the vertical distribution of resting eggs in sediment cores yield important information. Inferences can be made on variations of the environment over time. Changes over time in the populations which produce resting eggs, and the genetic differences between recent and past populations of the same species 
can be made [127]. Copepod resting eggs are particularly useful to reconstruct the history of their environment, since no information can be obtained from the exoskeleton, which is easily decomposed in contact with the sediments. This opens important perspectives for paleolimnological climate reconstruction and paleoecology [124].

Cultivation of live food, like rotifers, Daphnia, Artemia or marine copepods is an expanding application of practical use of diapause in modern aquaculture [82]. A better understanding of the timing mechanism of dormancy in these and many other species promises increase in efficiency of these biotechnologies [136].

Biotechnologies can now be imagined for maintaining ecosystems outside the Earth's biosphere. Using dormant plants and animals, one can envision the actual possibility of humans colonizing our nearest planets [12]. Resting stages provide at least two properties highly suitable for such ecosystems. They can easily be transported in space for a long time without special care as compared with an active ecosystem. Also, storage of seeds and diapausing animals will provide a reserve in case the active part of an ecosystem is destroyed by, for example, an unpredictable meteorite strike.

The term alien species takes on a new meaning when one considers another aspect of space biology. One day we will wish to know how to avoid contamination of other planets where life is possible with Earth organisms accidentally transported on space-research apparatus and human-led expeditions. The very strong stability of resting stages of primitive organisms, in particular, produces a real danger for such interplanetary penetration of alien species from the Earth. This ability of resting stages of many organisms to survive in open space is now under practical testing in order to produce biotechnology for interplanetary quarantine [12,89].

Many studies demonstrate that diapause provides the advantage of promoting colonization of new environments by facilitating the passive transport of the resting stages, for example, the ephippia [11,33, 58]. By enlarging the distribution area of the species, colonization of new environments could be a safeguard against its extinction. Furthermore, because diapausing animals are selected to overcome adverse periods, they have the advantage of being able to retain this characteristic in new environments as well. Thus it would be important to develop technologies to guard against invasions of these species via ship ballast waters or similar ways $[4,13,94]$.

It might be useful to consider diapause and its genetic mechanisms as a model of medical situations related to activation/suppression processes. Diapause mechanisms may, as well, be parallel with mechanisms of lethargic dream syndrome, some post-traumatic syndromes, some categories of disabled patients as well as carcinogenesis and aging [40,73].

Makrushin [72] observed that destructive and proliferative phenomena in diapause of some lower invertebrates are similar to destructive processes known in cancer of vertebrates. He speculated that there is a parallel between these particular pathological processes in vertebrates and seasonal body reduction associated with formation of the resting stage known in primitive metazoans. Following his hypothesis, cancer cells appear as a result of regressive development of tissue cells caused by activation of an ancient program (sleeping gene) of diapause formation.

When it was first published, the hypothesis was not taken seriously. There was very little critique by medical scientists or biologists, and the hypothesis was by no means considered testable. But to everyone's surprise, data obtained from molecular genetic studies of the nematode Caenorhabditis elegans support the idea of a common genetic basis for diapause and aging [52].

Recent studies have suggested that in C. elegans gene expression changes between the third larval stage diapause and reproductive development. A cascade of genes and their gene products mediates this choice between diapause and active development in $C$. elegans. These include $d a f-9$, a cytochrome $\mathrm{P} 450$ gene related to steroidogenic hydroxylases and $d a f-12$, a nuclear receptor gene encoding for those lipophilic hormones that control the physiological status of an organism [52].

A simple model is that the $d a f-9$ gene produces a hormone regulating $d a f-12$. Its gene product bypasses diapause, promotes reproductive development and, perhaps also shortens the life span. This hormone might be a sterol [53]. Expressed in potential endocrine tissues, daf-9 appears to control developmental decisions for the entire organism. Recent findings implicate $d a f-9$ as a central point of developmental control, producing hormonal signals that regulate $C$. elegans life history [52].

The choice between development and diapause can be regulated by several substances. Insulin is one such substance. Other signals which control the diapause program throughout the body are some specific peptides (TGFb) and serotonergic signaling [48]. Insulin and TGFb peptides are synthesized in response to environment stimuli, mainly from sensory neurons [69]. Alternatively, complex of the daf-3 and daf-5 genes affects a shift to diapause in adverse environments when TGFb inactivates $d a f-3$ and $d a f-5$, thus allowing reproductive development $[42,53]$. There is evidence that both insulin and $\mathrm{TGFb}$ receptors convey signals through 
downstream secondary endocrines and that daf-2 regulates diapause and life span by systemic signals $[19$, 134]. Much of this information has been collected from studies in which experimentally elicited mutants had lost either the capacity to activate cytochrome P450 (daf-9) or, alternatively, the nuclear receptor responsible for lipophilic hormone production (daf-12).

Mutants null for the gene daf-9 form diapausing larvae constitutively and have a life span about $25 \%$ longer than the normal form. Somewhat oppositely, daf-12 null mutants fail to form diapausing larvae and live short lives $[18,53]$. These observations establish a link between diapause and aging. There is also a link between aging and carcinogenesis [17].

The genes $d a f-9$ and $d a f-12$ have been linked with diapause. They have now been found in a very wide range of organisms from yeast to vertebrates. The genetic program coding diapause can either be actively used by organism, or simply kept "in reserve" by the genome without being expressed.

We here suggest a new hypothesis for carcinogenesis based on diapause gene expression. In cancer tumours there is a sudden shift from a quiet state to a state of fast division. We propose that it is the same mechanism responsible for diapause, for normal metabolism and also for the more active metabolism observed in some organisms after diapause termination [7, 23]. Further, this mechanism results from the activation of single gene (group of genes?) and it is hormone driven. Normal metabolism is the standard state of cells in an organism, and it is supported by a balance between the hormones activated by metabolism and those suppressed by metabolism. Both balance and misbalance as a normal adaptation to environmental demands have in fact been demonstrated in the moulting cycle of decapods $[1,7]$.

In this way, carcinogenesis then can appear as the result of an abnormal hormonal misbalance. The mechanism behind this could be triggered in a cell as a result of gene damage, whether from chemicals, radioactive or viral agents, or other causes. In this hypothetical cell, some normally-sleeping genes responsible for more active metabolism would suddenly become activated and the organism loses control of metabolism and division in these cells. In a normal, healthy organism, the immune system is able to recognize and kill these outof-control cells. In our supposed scenario, however, such a cell survives the immune system and starts intensively reproducing itself like a post-diapause embryo, developing into a carcinogenic tumour.

In our hypothesis, opposite to Cragie-Makrushin's hypotheses, cells in cancer tumours are parallel to post-diapausing embryonic cells driven by an out-ofcontrol hormone-activator. They are characterized by higher metabolic activity and division, as shown for the reactivated Daphnia embryo [24].

Our hypothesis, if substantiated through testing, will provide clinical scientists with diapause as a new model for cancer research. With it comes the promise of new medicine or treatment types aimed at normalizing the balance in hormonal mechanisms of cell metabolism.

\section{CONCLUSION}

Diapause is a very profound and ancient adaptation found in many classes of aquatic animals and plants. It appears likely that there is a monophyletic origin for this adaptation, as there is a similarity in the molecular basis and genetics of diapause mechanisms among organisms. Study on diapause in aquatic organisms opens many new scientific directions and technologically important applications in such fields as space research and invasive species control. When medical conditions originate from a misbalance in the activation/suppression process, diapause may offer a useful model for innovative treatment approaches. A new hypothesis of carcinogenesis process states that tumour cells are parallel with post-diapause embryonic cells.

\section{ACKNOWLEDGMENT}

We acknowledge the financial support from Taiwan (NSC 94-2311-B-019-009), and Russian (05-0490588-HHC_a) bilateral collaboration. Furthermore, we are grateful for the partial support of the RussiaJapan grant (05-04-50914-Я $\Phi \_$a) for our study in space, and partial support from Center for Marine Bioscience and Biotechnology, National Taiwan Ocean University to JS Hwang.

\section{REFERENCES}

1. Aiken, D.E., "Photoperiod, Endocrinology and the Crustacean Molt Cycle," Science, Vol. 164, pp. 149-155 (1969).

2. Aiken, D.E. and Waddy, S.L., "Reproductive Biology," in Cobb, J.S. and Phillips, B.F. (eds.), The Biology and Management of Lobster, Vol. 1, pp. 215-276, Physiology and Behaviour Academic Press, London, UK (1980)

3. Alekseev, V.R., "Effect of Chlorine Treatment on Zooplankton in Sturgeon Nursery Fish Ponds," Transaction of the State Lakes and Rivers Research Institute, Vol. 225, pp.95-104 (1984). (in Russian)

4. Alekseev, V.R., "Non-specific Resistance of Diapausing Crustaceans to Toxic Matter Treatments," Transaction of the State Lakes and Rivers Research Institute, Vol. 234, pp. 122-130 (1985). (in Russian) 
5. Alekseev, V.R., "Role of Diapause in Acclimatization of Crustaceans," Proceedings of GosNIORKH, Vol. 252, pp. 61-68 (1986). (in Russian)

6. Alekseev, V.R., Diapause in Crustaceans: Ecological and Physiological Aspects, Nauka Press, Moscow, p. 144, (1990). (in Russian)

7. Alekseev, V.R., "Biochemical and Physiological Characteristics of Crustaceans in Diapause: The Internal Mechanism of Reactivation," Archiv fur Hydrobiologie, Vol. 52, pp. 463-476 (1998).

8. Alekseev,V. R., "Effects of Dial Vertical Migration on Ephippia Production in Daphnia," Journal of Limnology, Vol. 63, pp. 1-6 (2004).

9. Alekseev, V.R. and Lampert, W., "Maternal Control of Resting-Egg Production in Daphnia," Nature, Vol. 414, pp. 899-901 (2001).

10. Alekseev, V.R. and Lampert, W., "Maternal Effects of Photoperiod and Food Level on Life History Characteristics of the Cladoceran Daphnia Pulicaria Forbes," Hydrobiologia, Vol. 526, pp. 225-230 (2004).

11. Alekseev, V.R. and Starobogatov, Y.I., "Types of Diapause in Crustacea: Definitions, Distributions, Evolution," Hydrobiologia, Vol. 320, pp. 15-26 (1996).

12. Alekseev, V.R. and Sychev, V.N., "Effect of Space Station Conditions on Resting Egg Survivorship and Parameters of Life Cycle in D. Magna," Abstract of COSPAR 2006, Beijin, China (2006).

13. Alekseev, V.R., Djenderedjan, K., and Fiks, B., "Role of Summer Diapause in Success of Invasion of a New Invertebrate Predator into Plankton Ecosystem of a Large Mountain Lake," Proceedings of $9^{\text {th }}$ International Conference Conservation and Management of Lakes, Biwako, Japan, pp. 41-47 (2001).

14. Alekseev, V.R., Pinel-Alloul, B., and Methot, J., "Role of Summer Cyclopid Diapause in Lake Meyobenthos Forming in Quebec Lakes (Canada)," Annual Scientific Session of Zoological Institute, Academic Publishers, St. Petersburg, pp. 8-9 (1999). (in Russian)

15. Alekseev, V.R., Sychev, V.N., and Novikova N.I., "Studying the Phenomenon of Dormancy: Why it is Important for Space Exploration," Abstract of COSPAR 2006, Beijin, China (2006).

16. Alekseev, V., Dumont, H., Pensaert, J., Baribwegure, D., and Vanfleteren, J. R., "A redesctiption of Eucyclops Serrulatus (Fischer, 1851) (Crustaceaa, Copepoda, Cyclopoida) and Some Related Taxa, with a Phylogeny of the E. Serrulatus-Group," Zooogica Scripta, Vol. 35, pp. 123-158 (2006).

17. Anisimov, V.N., Carcinogenesis and Aging, CRC Press, Doca Raton, FL (1987).

18. Antebi, A., Yeh, W. H., Tait, D., Hedgecock, E. M., and Riddle, D. L., "Daf-12 Encodes a Nuclear Receptor That Regulates the Dauer Diapause and Developmental Age in C. Elegans," Genes and Development, Vol. 14, pp.
1512-1527 (2000).

19. Apfeld, J. and Kenyon, C., "Cell Nonautonomy of C. Elegans Daf-2 Function in the Regulation of Diapause and Life Span," Cell, Vol. 95, pp. 199-210 (1998).

20. Arbačiauskas, K., "Life-History Traits of Exephippial and Parthenogenetically Derived Daphnids: Indicators of Different Life-History Strategies," Archiv für Hydrobiologie Special Issues Advances in Limnology, Vol. 52, pp. 339-358 (1998).

21. Arbačiauskas, K., "Life-History Variation Related to the First Adult Instar in Daphnids Derived from Diapausing and Subitaneous Eggs," Hydrobiologia, Vol. 442, pp. 157-164 (2001).

22. Arbačiauskas, K., "Seasonal Phenotypes of Daphnia: Post-Diapause and Directly Developing Offspring," Journal of Limnology, Vol. 63, pp. 7-15 (2004).

23. Arbačiauskas, K. and Lampert, W., "Seasonal Adaptation of Ex-Ephippio and Parthenogenetic Offspring of Daphnia Magna: Differences in Life-History and Physiology," Functional Ecology, Vol. 17, pp. 431-437 (2003).

24. Askerov, M.K. and Sidorov, P.A., "Biology of Phyllopods in Sturgeon Ponds and Struggle Against the Crustaceans," Transactions of the Azerbajdjan Research Institute of Fish Industry, Vol. 4, pp. 83-97 (1964). (in Russian)

25. Banta, A.M. and Brawn, L.A., "Control of Sex in Cladocera. 1 Crowding the Mothers as a Means of Controlling Male Production," Physiological Zoology Vol. 2, pp. 80-92 (1929).

26. Behning, A.L., Cladocera of the Caucuses, Gruzmedizdat, Tbilisi, Georgia (1941). (in Russian)

27. Berg, K., "Cyclic Reproduction, Sex Determination and Depression in Cladocera," Cambridge Biological Reviewes, Vol. 9, pp. 139-174 (1934).

28. Bertalanffy, L.Von., Study on Common Theory of Systems, Progress Publisher, Moscow (1969). (in Russian)

29. Bogatova, I.B. and Erofeeva, G.I., "Incubation of Artemia Salina Resting Eggs without Preliminary Stimulation," Hydrobiologicheskij Journal, Vol. 21, pp. 52-56 (1985). (in Russian)

30. Bouchon, D., Remoissenent, G., and Mocquard, J.P., "Influence de La Temperature Sur 1'Entree en Reproduction de Palaemonetes Varians Leach (Crustace, Decapoda, Natantia)," Bulletin Sciences Zool of France, Vol. 110, pp. 439-447 (1985).

31. Branford G.K., "The Influence of Day-Length, Temperature and Season on the Hatching Rhythm of Homarus Gammarus," Journal Marine Biological Association U. K., Vol. 58, pp. 639-658 (1978).

32. Burner, H.C. and Halcrow, K., "Experimental Induction of the Production of Ephippia by Daphnia Magna Straus (Cladocera)," Crustaceana, Vol. 32, pp. 77-86 (1977).

33. Cáceres, C.E., "Temporal Variation, Dormancy, and Coexistence: A Field Test of the Storage Effect," Pro- 
ceedings of the National Academy of Sciences, U.S.A., Vol. 94, pp. 9171-9175 (1997).

34. Carvalho, G.R. and Wolf, H.G., "Resting Eggs of LakeDaphnia I. Distribution, Abundance and Hatching of Eggs Collected from Various Depths in Lake Sediments," Freshwater Biology, Vol. 22, pp. 459-470 (1989).

35. Champeau, A., "Etude de La Vie Latente Chez des Calanoides (Copepodes) Caracteristiques des Eaux Temperairres de Basse-Provence," Annales de la Faculte des Sciences de Marseille, Vol. 44, pp. 155-189 (1970).

36. Coker, R.E., "Arret du Developpement Chez Les Copepodes," Bulletin of Biology, Vol. 67, pp. 276-287 (1933).

37. Cooley, J.M., "The Effect of Temperature on the Development of Resting Eggs of Diaptomus Oregonensis Lillj (Copepoda:Calanoida)," Limnology and Oceanography, Vol. 16, pp. 921-926 (1971).

38. Cooper, C.S. and Grover, P.L., Chemical Carcinogenesis and Mutagenesis, Springer Verlag, Berlin(1990).

39. Cousyn, C. and De Meester, L., "The Vertical Profile of Resting Egg Banks in Natural Populations of the PondDwelling Cladoceran Daphnia magna Straus," Archiv fur Hydrobiologie (Special Issues), Vol. 52, pp. 127-139 (1998).

40. Craigie, J., Lind, P.E., Hayward, M.E., and Begg, A.M., "Preliminary Observation on a "Dormant" State of Sarcoma Cells with Special References to Resistance to Freesing and Drying," Journal of Pathology and Bacteriology, Vol. 63, pp. 177-178 (1951).

41. Crisp, D.J. and Patel, B., "Environmental Control of the Breeding of Three Boreoarctic Cirripedes," Maine Biology, Vol. 2, pp. 283-295 (1969).

42. Da Cassada Graca, L. S., Zimmerman, K. K., Mitchell, M. C., Kozhan-Gorodetska, M., Sekiewicz, K., Morales, Y., and Patterson, G. I., "DAF-5 is a Ski Oncoprotein Homolog That Functions in a Neuronal TGFb Pathway to Regulate C. Elegans Dauer Development," Development, Vol. 131, pp. 435-446 (2003).

43. Danilevsky, A.S., Photoperiodism and Seasonal Development of Insects, Leningrad State University Press, Leningrad (1961). (In Russian)

44. De Meester, L., Gomes, A., and Simon, J.-C., "Evolutionary and Ecological Genetics of Cyclical Parthenogens," in Moya, A. and Font, E. (eds.), Evolution from Molecules to Ecosystems, University Press, Oxford, pp. 109-121 (2003).

45. De Stasio, B.T., Jr., "The Seed Bank of a Freshwater Crustacean: Copepodology for the Plant Ecologist," Ecology, Vol. 70, pp. 1377-1389 (1989).

46. De Stasio, B.T., Jr., "The Role of Dormancy and Emergence Patterns in the Dynamics of a Freshwater Zooplankton Community," Limnology and Oceanography, Vol. 35, pp. 1079-1090 (1990).

47. Einsle, U., "Die Ausseren Bedingungen Der Diapause
Plankisch Lebender Cyclops-Arten," Archiv für Hydrobiologie, Vol. 63, pp. 387-403 (1967).

48. Finch, C. E. and Ruvkun, G., "The Genetics of Aging," Annual Review of Genomics and Human Genetics, Vol. 2, pp. 435-462 (2001).

49. Fries, G., "Uber Die Einwirkung Der Tagesperiodik Und Der Temperatur Auf Den Generationswechsel, Die Weibchengrosse Und Die Eir von Daphnia Magna Straus," Zeitschrift für Morphologie und Ökologie der Tiere, Vol. 53, pp. 475-516 (1964).

50. Fryer, G., "Diapause a Potent Force in the Evolution of Freshwater Crustaceans," Hydrobiologia, Vol. 320, pp. 1-14 (1996).

51. Fryer, G. and Smyly, W.I.P., "Some Remarks on the Resting Stagees of Some Fresh Water Cyclopoid and Harpacticoid Copepods," The Annals and Magazine of Natural History, Vol. 7, pp. 65-72 (1954).

52. Gerisch, B. and Antebi, A., "Hormonal Signals Produced by DAF-9/Cytochrome P450 Regulate $C$. Elegans Dauer Diapause in Response to Environmental Cues," Development, Vol. 131, pp. 1765-1776 (2004).

53. Gerisch, B., Weitzel, C., Kober-Eisermann, C., Rottiers, V., and Antebi, A., "A Hormonal Signaling Pathway Influencing C. Elegans Metabolism, Reproductive Development, and Life Span," Developmental Cell, Vol. 1, pp. 841-851 (2001).

54. Gilbert, J.J., "Population Density, Sexual Reproduction and Diapause in Monogonont Rotifers: New Data for Brachionus and a Review," Journal of Limnology, Vol. 63 (Suppl.1), pp. 32-36 (2004).

55. Gliwicz, Z.M. and Rowan, M.G., "Survival of Cyclops Abyssorum Tatricus (Copepoda, Crustacea) in Alpine Lakes Stocked with Planktivrous Fish," Limnology and Oceanography, Vol. 29, pp. 1290-1299 (1984).

56. Grosvener, G. and Smith, G., "The Life Cycle of Moina Rectirostris," Quarterly Journal Microscopic Society, Vol. 58, pp. 87-112 (1913).

57. Gutierres, J.C., Martin-Gonzales, A., and Matsusaka, T., "Toward to a Generalized Model of Encystment (Cryptobiosis) in Ciliates: a Review and Hypothesis," Biosystems, Vol. 24, pp. 17-24 (1990).

58. Hairston, N.G., Jr. and Caceres, C., "Distribution of Crustacean Diapause: Micro- and Macroevolutionary Pattern and Process," Hydrobiologia, Vol. 320, pp. 2744 (1996).

59. Hairston, N.G., Jr. and De Stasio., B.T., "Rate of Evolution Slowed by a Dormant Propagule Pool," Nature, Vol. 336, pp. 239-242 (1988).

60. Hairston, N.G., Jr., and Olds, E.J., "Population Differences in the Timing of Diapause: A Test of Hypotheses," Oecologia, Vol. 71, pp. 339-344 (1987).

61. Herman, A. W., Sameoto, D.D., and Longhurst, A.R., "Vertical and Horizontal Distribution Patterns of Copepods Near the Shelf. Break Front South of Nova Scotia, 
Canad," Journal Fish and Aquatic Sciences, Vol. 38, pp. 1065-1076 (1981).

62. Hirche, H.-J., "Diapause in the Marine Copepod, Calanus Finmarchicus, A Review," Ophelia, Vol. 44, pp. 129143 (1996).

63. Ivleva, I.V., Temperature and Metabolic Rates in Aquatic Animals, Naukova Dumka Publishers, Kiev (1981). (in Russian)

64. Jassem, W., Mocquard, J.P., and Juchault, P., "Determinisme de La Reproduction Saisonniere des Femelles d'Armadillidium Vulgare Latr. (Crustace, Isopode, Oniscoide) IV. Contribution a la Connaissance de la Perception du Signal Photopreriodique in Duisant 1 'entree en Reproduction: Mode de Discrimination Entre Ie Jour et la Mit Longueurs d'onde Actives," Annales des Sciences Naturelles-Zoologie et Biologie Animale, Vol. 4, pp. 85-90 (1982).

65. Juchault, P., Pavese, A., and Mocquard, J.P., "Determinisme de la Reproduction Saisonniere des Femelles d'Armadillidium Vulgare Latr. (Crustacea, Isopode, Oniscoide) II. Etude Phiques Differentes," Annales des Sciences Naturelles, Zoologie et Biologie Animale, Vol. 2, pp. 99-108 (1980).

66. Kubersky, E.S., "Worldwide Distribution and Ecology of Alonopsis (Cladocera, Chydoridae) with a Description of Alonopsis Americana sp. Nova," International Review of Hydrobiology, Vol. 62, pp. 649-685 (1977).

67. Lampert, W., "Evolutionary Ecology: Natural Selection in Freshwater Systems," in Moya, A. and Font, E. (eds.) Evolution from Molecules to Ecosystems, University Press, Oxford, pp.109-121 (2003).

68. Lee, C.L. and Fieder, D.R., "Induced Spawning in the Freshwater Prawn, Macrobrachium Australiense Holthuis 1950 (Crustacea. Decapoda: Palaemonidae)," Aquaculture, Vol. 29, pp.45-52 (1982).

69. Li, W., Kennedy, S. G., and Ruvkun, G., "Daf-28 Encodes a C. Elegans Insulin Superfamily Member That is Regulated by Environmental Cues and Acts in the DAF2 Signaling Pathway," Genes and Development, Vol. 17, pp. 844-858 (2003).

70. Little, G., "Induced winter Breeding and Larval Development in the Shrimp Palaemonetes Pugio (Holthius)," Crustaceana, (Supplement) Vol. 2, pp. 19-26 (1968).

71. Makrushin, A.V., "Condition of Ephippial Female Ovary in Some Cladocera Species," Transactions of the State Lakes and Rivers Research Institute, Vol. 67, pp. 365369 (1968). (in Russian)

72. Makrushin, A.V., "Evolutionary Predecessors of Oncogenesis and Old Age Involution," Advanced Gerontol, Vol.13, pp. 32-43 (2004).

73. Makrushin, A. V. and Khudoley, V.V., "Opuhol Kak Atavisticheskaja Reakzija na Uslovija Okrugajushej Sredy (Tumor as an Atavistic Response on Environmental Stress)," Journal Obshej Biologii, Vol. 52, pp. 717-
722 (1991). (in Russian)

74. Makrushin, A. V. and Lyanguzova, I.V., "The Shell of Invertebrates and Plant Propagules: Selective Permeability and Barriers.” Journal Obshej Biologii, Vol. 67, pp. 115-122 (2006). (in Russian)

75. Makrushin, A. V. and Stepanova, I.E., “Ob Izberatenoj Pronizaemosti Obolochek Latentnuh Jaiz Moina Macrocopa (Daphniiformes, Crustacea). (On the Selective Permeability of Covering Membrane in Moina Macrocopa Restin Eggs)," Zoologicheskij Journal, Vol. 82, pp. 117-118 (2003).

76. Mansingh, A., "Physiological Classification of Dormencies in Insects," Canadian Entomologist, Vol. 103, pp. 983-1009 (1971).

77. March, B.G.E., "Decreased Day Lenght and Light Intensity as Factors Inducing Reproduction in Gammarus Lacustris Sars," Canadian Journal of Zoology, Vol. 60, pp. 2962-2965 (1982).

78. Marcus, N.H., "Photoperiodic and Temperature Regulation of Diapause in Labidocera Aestiva (Copepoda: Calanoida)," Marine Ecology-Progress Series, Vol. 162, pp. 45-52 (1982).

79. Marcus, N.H., "Recruitment of Copepod Nauplii Into the Plankton: Importance of Diapause Eggs and Benthic Processes," Marine Ecology-Progress Series, Vol. 15, pp. 47-54 (1984).

80. Marcus, N.H., "Population Dynamics of Marine Copepods: The Importance of Photoperiodism," American Zoologist, Vol. 26, pp. 469-477 (1986).

81. Marcus, N.H., "Ecological and Evolutionary Significance of Resting Eggs in Marine Copepods: Past, Present and Future Studies," Hydrobiologia, Vol. 320, pp. 141152 (1996).

82. Marcus, N.H., Lutz, R.V., Burnett, W., and Cable, P., "Age, Viability, and the Vertical Distribution of Zooplankton Resting Eggs from an Anoxic Basin: Evidence of an Egg Bank," Limnology and Oceanography, Vol. 39, pp. 154-158 (1994).

83. Mocquard, J.P. and Juchault, P., "Photoperiode et Reproduction Chez Les Femelles d'Armadillidium Vulgare Latreille (Crustacea, Isopode, Oniscoide): Variation en Fonction de 1'origine Geographique des Populations," Bulletin de la Societé Zoologique de France, Vol. 110, pp. 425-439 (1985).

84. Monchenko, V.I., Free Living Cyclopoid Copepods of the Pontho-Caspian Basin, Naukova Dumka Academic Publishers, Kiev (2003). (in Russian)

85. Mortimer, C.H., "Experimentelle Und Cytologische Untersuchungen Liber Den Generationswechsel Der Cladoceren," Zoologische Jahrbuecher Abteilung fuer Allgemeine Zoologie und Physiologie der Tiere, Vol. 56, pp. 323-388 (1936).

86. Munuswamy, N., Nazar, A.K., and Dumont, H.J., "Is pH (i) a Factor for Dormancy in Freshwater Fairy Shrimps," 
Current Science, Vol. 62, pp. 751-752 (1992).

87. Nilssen, J.P., "On the Evolution of Life Histories of Limnetic Cyclopoid Copepods," Memorie Dell'Istituto Italiano di Idrobiologia, Vol. 36, pp. 193-214 (1978).

88. Nilssen, J. and Elgmork, K., "Cyclops Abyssorum - Life Cycle Dynamic and Habitat Selection," Memorie Dell'Istituto Italiano di Idrobiologia, Vol. 34, pp. 197238 (1977).

89. Novikova, N.D., "The Concept of Microbiological Safety of a Piloted Martian Expedition," Aerospace and Ecology Medicine, Vol. 37, pp. 56-59 (2003). (in Russian)

90. Odum, E.P., Ecology, Holt Rinehardt and Winston, New York (1963).

91. Olmstead, A.W. \& LeBlanc, G.A., "Insecticidal Juvenile Hormone Analogs Stimulate the Production of Male Offspring in the Crustacean Daphnia Magna," Environmental Health Perspectives, Vol. 111, pp. 919-924 (2003).

92. Owen, R.W., "Fronts and Eddies in the Sea: Mechanism, Interactions and Biological Effects," In Longhurst, A.R. (eds.), Analysis of Marine Ecosystems, Academic Press, San Francisco, pp. 197-233 (1981).

93. Pancella, J.R. and Stross, R.G., "Light Induced Hatching of Daphnia Resting Eggs," Chesapeake Science, Vol. 4, pp. 404-425 (1963).

94. Panov, V.E., Krylov, P.I., and Riccardi, N., "Role of Diapause in Dispersal and Invasion Success by Aquatic Invertebrates," Journal of Limnology, Vol. 63, pp. 56-69 (2004).

95. Pijanowska, J., "Alarm Signals in Daphnia," Oecologia, Vol. 112, pp. 12-16(1997).

96. Pourriot, R. and Clement, P., "Photoperiodisme et Cycle Heterogonique Chez Notommata Copeus (Rotifere, Monogonorte) II. In Fluence de Gualite de la Lumiere Spectres d'action," Archives de Zoologie Experimentale and Generale, Vol. 114, pp. 277-300 (1973).

97. Sarojini, R. and Gyananth, G., "Photoperiodic Regulation of Ovarian Maturation in the Freshwater Prawn Macrobrachium Lamerr," Journal of Current Bioscience, Vol. 2, pp. 158-162 (1985).

98. Sarvala, J., "Bentic Resting Periods of Pelagic Cyclopods in an Oligotrophic Lake," Holarctic Ecoogy, Vol. 2, pp. 88-100 (1979).

99. Scharfenberg, Von., "Weitere Untersuchungen an Cladoceren Liber die Experimentel Lebeeinflussung des Geschlechts und der Dauereibildung," Internationale Revue der Gesamten Hydrobiologie, Vol. 6, pp. 1-34 (1914).

100. Shan, R.K., "Reproduction in Laboratory Stocks of Pleuroxus (Chydoridae, Cladocera) under Influence of Photoperiod and Light Intensity," Internationale Revue der Gesamten Hydrobiologie, Vol. 59, pp. 643-666 (1974).

101. Shan, R.K. and Frey, D.G., "Induced Interbreeding between Two Stocks of a Chydorid Cladoceran,"
Bioscience, Vol. 18, pp. 203-205 (1968).

102. Shull, A.F., "Origin of Diverse Strains of an Aphid Species within a Limited Area," Papers, Michigan Academy of Science, Arts, and Letters, Vol. 28, pp. 425431 (1943).

103. Slusarczyk, M., "Predator-Induced Diapause in Daphnia," Ecology, Vol. 76, pp. 1008-1013 (1995).

104. Smirnov, N.N., Chydoridae of the World, Nauka Academic Publishers, Leningrad (1971). (in Russian)

105. Smyly, W.J.P., "Laboratory Experiments with Stage V Copepodids of the Freshwater Copepod, Cyclops Leuckarti Claus, from Windemere and Easthwaite Water," Crustaceana, Vol. 4, pp. 273-280 (1962).

106. Spectrova, L.V., Recommendations for Artemia Culturing and Using in Aquaculture, Viniti Center, Moscow, (1984). (in Russian)

107. Spindler, K.D., "Untersuchungen Fiber den Einfiup Auperer Faktoren auf die Darner der Embryonalentwicklung und der Hantungsrhythuns von Cyclops Vicinus," Oecologia, Vol. 7, pp. 342-355 (1971).

108. Steele, V.J., "The Effect of Photoperiod on the Reproductive Cycle of Gammarus Lawrencianus Bousfield," Journal of Experimental Marine Biology and Ecology, Vol. 53, pp. 1-7 (1981).

109. Strempel, K.M., "Paarung, Erbriitung und Brutpflege des Europaischen und Amerikanischen Edelkrebses (Astacus Astacus und Pacifastacus Leniusculus) unter Dem Gesichtspunkt der Kunstlichen Aufzucht," Arbeiten des Deutschen Fischereiverbandes, Vol. 19, pp. 125129 (1976).

110. Stross, R.G., "Termination of Summer and Winter Diapause in Daphnia," American Zoologist, Vol. 15, pp. 701 (1965).

111. Stross, R.G., "Light and Temperature Requirement for Diapause Development and Release in Daphnia," Ecology, Vol. 47, pp. 368-374 (1966).

112. Stross, R.G., "Photoperiod Control of Diapause 142 in Daphnia. II. Induction of Winter Diapause in the Arctic," The Biological Bulletin, Vol. 136, pp. 264-273 (1969).

113. Stross, R.G., "Photoperiodism and Diapause in Daphnia: a Strategy for All Seasons," Transactions of American Microscopicsl Society, Vol. 90, pp. 110-112 (1971).

114. Stross, R.G., "Photoperiodism and Phased Growth in Daphnia Populations: Coactions in Perspective," in R. H. Peters and R. de Bernardi (eds.), Daphnia. Memorie dell'Istituto Italiano di Idrobiologia, Vol. 45, pp. 413437 (1987).

115. Stross, R.G. and Chisholm, S.W., "Density Stabilization in Arctic Populations of Daphnia," Verhandlungen International Vereiningung Limnologie, Vol. 19, pp. 2879-2884 (1975).

116. Stross, R.G. and Kansas, D.A., "The Reproductive Cycle of Daphnia in an Arctic Pool," Ecology, Vol. 50, 
pp. 457-460 (1969).

117. Stuart, C. and Banta, A., "Available Bacteria and the Sex Ratio in Moina," Physiological Zoology, Vol. 4, pp. 654-696 (1931).

118. Tcherkashina, N.J. and Karnaushenko, I.V., "Beforeembryonic Diapause in Cray-Fish (Astacus Leptodactilis Cubanicus Bir. et Win.)," Journal Obshej Biologii, Vol. 43, pp. 687-689 (1982). (in Russian)

119. Thiriot, A., "Zooplankton Communities in the West African Upwelling Area," In Boje, R. and Tomczak, M. (eds.), Upwelling Ecosystems, Springer-Verlag, Berlin, pp. 32-61 (1978).

120. Tsukerzis, J.M. and Shashtokas, I.A., "Embryonic Diapause in the Noble Cray-Fish (Astacus Astacus L.)," Journal Obshej Biologii, Vol. 38, pp. 929-933 (1977). (in Russian)

121. Tyshenko, V.P., Physiology of Insect Photoperio-dism, Nauka Academic Publishers, Leningrad (1977). (in Russian)

122. Ulomsky, S.N., "News in Ecology of Some Mesocyclops," Doklady Academic Science of USSR, Vol. 90, pp. 295-297 (1953). (in Russian)

123. Uye, S., Kasahara, S., and Onbe, T., "Calanoid Copepod Eggs in Sea-Bottom Muds. IV. Effects of Some Environmental Factors on the Hatching of Resting Eggs," Marine Biology, Vol. 51, pp. 151-156 (1979).

124. Verschuren, D., Cocquyt, C., Tibby, J., Roberts, C. N., and Leavitt, P.R., "Long-Term Dynamics of Algal and Invertebrate Communities in a Fluctuating Tropical Soda Lake," Limnology and Oceanography, Vol. 44, pp. 1216-1231(1999).

125. Watson, N.H.F. and Smallman, B.N., "The Role of Photoperiod and Temperature in the Induction and Termination of an Arrested Development in Two Species of Freshwater Cyclopid Copepods," Canadian Journal of Zoology, Vol. 49, pp. 855-862 (1971).

126. Winberg, G.G., "Cyclic Breeding in Cladocera," Uspehi Sovremennoj Biologii, Vol. 5, pp. 201-202 (1936). (in Russian)

127. Weider, L.J., Lampert, W., Wessels, M., Colbourne, J. K., and Limburg, P., "Long-Term Genetic Shifts in a Microcrustacean Egg Bank Associated with Anthropogenic Changes in the Lake Constance Ecosystem," Proceedings of the Royal Society of London Series B, Vol. 264, pp. 1613-1618 (1997).
128. Weismann A., "Beitrage Zur Naturgeschichteder Daphnoiden," Zeitschrift für Wissenschaftliche Zoologie, Vol. 33, pp. 55-270 (1880).

129. Westin, L. and Gydemo, R., "Influence of Light and Temperature on Reproduction and Moulting Frequency of the Crayfish Astacus Astacus L.," Aquaculture, Vol. 52, pp. 43-50 (1986).

130. Wierzbicka, M., "On the Resting Stage and Mode of Life of Some Species of Cyclopoida," Polskie Archiwum Hydrobiologii, Vol. 10, pp. 216-229 (1962).

131. Williams, J.A., "The Light-Response Rhythm and Seasonal Entrainment of the Endogenous Circadian Locomotor Thythm of Talitrus Saltator (Crustacea, Amphipoda)," Journal of the Marine Biological Association of the UK, Vol. 60, pp. 773-785 (1980).

132. Williams-Howze, J., "Dormancy in the Free-Living Copepods Orders Cyclopoida, Calanoida and Harpacticoida," Oceanography and Marine Biology, An Annual Review, Vol. 35, pp. 257-321 (1996).

133. Wolf, H.G. and Carvalho, G.R., "Resting Eggs of LakeDaphnia II. In Situ Observations on the Hatching of Eggs and Their Contribution to Population and Community Structure," Freshwater Biology, Vol. 22, pp. 471-478 (1989).

134. Wolkow, C.A., Kimura, K.D., Lee, M.S., and Ruvkun, G., "Regulation of C. Elegans Life-Span by InsulinLike Signaling in the Nervous System," Science, Vol. 290, pp. 147-150 (2000).

135. Woltereck, R., "Ober Veranderung Der Sexualitat Bei Daphniden," Internationale Revue der Gesamten Hydrobiologie, Vol. 4, pp. 91-128 (1911).

136. Zadereev, Ye.S., "Maternal Effects, Conspecific Chemical Cues, and Switching from Parthenogenesis to Gametogenesis in the Cladoceran Moina macrocopa," Aquatic Ecology, Vol. 37, pp. 251-255 (2003).

137. Zaffagnini, F., "Reproduction in Daphnia," Memorie Dell'Istituto Italiano Di Idrobiologia, Vol. 45, pp. 245284 (1987).

138. Zavadovsky, M.M., "O Lipoidnoj Polupronizaemosti Obolochki Jaza Ascaris Megalocephala (On Lipoid One-Way Permeability of Protective Membrane in Ascaris Megalocephala Resting Egg)," Uchenye Zapiski Moskovskogo Gorodskogo Narodnogo Universiteta, Vol. 1, pp. 5-122 (1915). (in Russian) 